\title{
Social support for patients with type 2 diabetes and metabolic control of the disease
}

\author{
Wsparcie społeczne pacjenta z cukrzycą typu 2 a wyrównanie \\ metaboliczne choroby
}

\author{
Karolina Ewa Ciemińska',A-F® ${ }^{1, E w a ~ K o b o s}{ }^{2, A, D-F} \odot$ \\ ${ }^{1}$ Warsaw Medical University, Poland \\ ${ }^{2}$ Faculty of Health Sciences, Medical University, Warsaw, Poland \\ A - Research concept and design, B - Collection and/or assembly of data, C - Data analysis and interpretation, \\ $D$ - Writing the article, E-Critical revision of the article, F- Final approval of article \\ Ciemińska KE, Kobos E. Social support for patients with type 2 diabetes and metabolic control of the disease. Med Og Nauk Zdr. 2020; 26(1): \\ 42-47. doi: $10.26444 / \mathrm{monz} / 118404$
}

\section{Abstract}

Objectives. To achieve normoglycaemia and maintain correct parameters of disease compensation, as well as analysis of the impact of social support on the values of metabolic control parameters of type 2 diabetes.

Materials and method. The study involved 79 patients with type 2 diabetes staying in a diabetology clinic. To collect the research material, the Social Support Scale (S4-MAD) and the results of patient measurements and tests were used, such as blood pressure, weight, height, and laboratory test results: glycated haemoglobin, full lipidogram (triglycerides, total cholesterol, LDL and HDL).

Results. Patients received the most support in the field of nutrition ( $S=46.9 / 100$ points), the least in the field of foot care $(S=25.3 / 100$ points). With the increase in social support in 4 sub-scales of the MAD-4 scale, a decrease in diastolic blood pressure was demonstrated. Greater support in the area of self-control resulted in lowering the total cholesterol value, in the area of cigarette smoking, in lowering systolic and diastolic pressure.

Conclusions. Patients who receiving higher social support have better metabolic control results. Due to the low level of social support for patients with diabetes, healthcare professionals should include family members in education and care whenever possible to provide more support to patients and pay more attention to non-clinical factors in addressing diabetes-related problems. They should also remember that interventions based on psychosocial approaches may not necessarily improve the metabolic control assessed by the values of clinical indicators, but they can affect the quality of life of patients.

\section{Key words}

social support, type 2 diabetes, metabolic control

\section{Streszczenie}

Cel pracy. W leczeniu cukrzycy dąży się do normoglikemii oraz utrzymania prawidłowych parametrów wyrównania choroby. Celem pracy jest ocena wpływu wsparcia społecznego pacjenta z cukrzycą typu 2 na wybrane wskaźniki wyrównania metabolicznego cukrzycy.

Materiał i metody. W badaniu udział wzięło 79 chorych na cukrzycę typu 2, przebywających w poradni diabetologicznej. Do zebrania materiału badawczego wykorzystano Skalę Wsparcia Społecznego (S4-MAD) oraz wyniki pomiarów i badań pacjentów, takich jak wyniki pomiarów ciśnienia tętniczego krwi, masy ciała, wzrostu, oraz wyniki badań laboratoryjnych: hemoglobiny glikowanej i stężenia lipidów (trójglicerydy, cholesterol całkowity, LDL, HDL).

Wyniki. Pacjenci otrzymują najwięcej wsparcia w zakresie odżywiania ( $S=46,89 / 100$ pkt), najmniej w zakresie pielęgnacji stóp ( $S=25,30 / 100$ pkt). Wykazano, iż wraz ze wzrostem wsparcia społecznego w 4 subskalach skali MAD-4 następuje obniżenie wartości ciśnienia rozkurczowego krwi. Większe wsparcie w zakresie samokontroli wpływało na obniżenie wartości cholesterolu całkowitego, w zakresie palenia papierosów - na obniżenie wartości ciśnienia skurczowego i rozkurczowego.

Wnioski. Pacjenci otrzymujący większe wsparcie społeczne uzyskują lepsze wyniki wyrównania metabolicznego. Niestety obserwuje się niski poziom wsparcia społecznego osób z cukrzycą. Dlatego też pracownicy ochrony zdrowia powinni zawsze gdy jest to możliwe edukować członków rodzin pacjentów i włączać w opiekę nad nimi, aby zapewnić chorym silniejsze wsparcie, a także zwracać większą uwagę na czynniki niekliniczne przy rozwiązywaniu problemów związanych z cukrzycą. Powinni także pamiętać, że interwencje oparte na podejściu psychospołecznym niekoniecznie poprawiają kontrolę metaboliczną ocenianą na podstawie wartości wskaźników klinicznych, ale mogą wpływać na jakość życia pacjentów.

\section{Słowa kluczowe}

wsparcie społeczne, cukrzyca typu 2, wyrównanie metaboliczne

\footnotetext{
Addres for correspondence: Karolina Ewa Ciemińska, Medical University, Warsaw, Zwirki i Wigury 61, 02-091, Warsaw, Poland

E-mail: karolin.cieminska@gmail.com

Received: 27.11.2019; accepted: 24.02.2020; first published: 10.03.2020
} 


\section{INTRODUCTION}

Type 2 diabetes is a chronic disease that occurs mainly in adults. In Poland in 2017, over 2 million people aged 20-79 suffered from diabetes. In 2045, there will be 165,000 more. This is, respectively, $7.6 \%$ of the total Polish population and $9.1 \%$ of the total European population [1]. In the treatment of diabetes, normoglycaemia is sought for as well as maintaining normal parameters of disease compensation [2]. Due to its chronic nature, diabetes is difficult to treat even if the patient follows the instructions. In the last decades, the role of psychological and sociological factors has been analyzed searching for their impact on the outcome of diabetes treatment. The Trief et al. study [3] has been shown that the coexistence of depression with diabetes has a negative impact on the results of treatment. A higher sense of coherence, or a sense of understanding events, resourcefulness of creating one's own life, positively affects the maintenance of normoglycaemia [4, 5]. Already in the 1990s, it was found that both psychiatric and somatic disorders were more common in communities where family ties were affected. It has been concluded that social support has a positive effect on disease progression [6]. Such observations prompted the undertaking of research to assess the role of social support in the management of diabetes parameters.

Social support, due to its multifaceted nature, can be defined in three ways. Social support as a relationship of at least two people who exchange experiences; social support as a way of satisfying the social needs of a given person through various types of interactions with people, and social support as a sense of belonging of an individual to society [7]. Social support can come from family, friends, as well as from health care workers. Demand for support may vary depending on race, origin, gender and culture. The sense of support and acceptance from society allows patients to accept the disease and better control it [8].

Normoglycaemia is largely dependent on the patients themselves. Strict regularity in life, amount of physical exertion, and the use of a diet are crucial in diabetes equalization. Unfortunately, for a large number of patients thist does not come easily. It can be argued that in order to achieve these recommendations, one need the motivation that the patients receive from their loved ones. Social support of family and friends is considered as informal support and consists in providing the patient with a sense of acceptance and care. Family members can facilitate or hinder activities related to self-care. They can over-compensate the patient in buying food products or exchanging insulin in the pen, so that a person with diabetes is not responsible for the equalization of glycaemic and other metabolic control parameters. The family can also generate stress in the patient, which will result in hyper- and hypoglycaemia. Nevertheless, the closest family members are very important because they provide a sense of security and provide emotional support [9].

Kang et al. showed that support of the family without their knowledge about the disease is not effective, does not improve the patient $>$ results, nor do the patients themselves feel supported. Despite the fact that in families in which members received diabetes education, the level of glycated haemoglobin and lipidogram parameters did not improve, supportive behaviours increased, the level of knowledge about the disease increased, and attitudes towards diabetes improved [10]. The need to include the family in education was also highlighted in a study evaluating family support in various aspects of the life of a diabetic patient on the results of glycosylated haemoglobin, lipidogram and glucose. It was shown that family support and knowledge about diabetes is low, which means that it has a limited ability to take proper care of the patients [11].

To-date, no study in Poland has identified the impact of social support on indicators of metabolic equalization of type 2 diabetes taking into account eight clinical indicators. Support relationships are valuable and often considered necessary to provide guidance and encouragement, especially when the patient begins and continues with new behaviours and requires making informed, often life-changing, health decisions [8].

\section{MATERIALS AND METHOD}

Participants and setting. The cross-sectional study was carried out at a diabetology clinic during doctor $>$ s check-ups in the period January - April 2018, involving 79 patients (43 women and 36 men) with type 2 diabetes. Inclusion criteria: a) patient s age at least 30 years, b) duration of the disease for at least 1 year, c) included pharmacological treatment of diabetes. The mean age of the respondents was 64 years $(\mathrm{SD}=10)$. There were 52 patients who were married, 21 were widowers, and 6 unmarried.

Procedure. During the visit to a nurse in the Diabetes Clinic, each patient filled out a questionnaire covering socio-demographic and clinical data, as well as the scale of social support. The nurse measured blood pressure, body weight and height, and calculated the body mass index (BMI). Blood samples were collected from the patient in the treatment room after visiting the doctor. The results of blood tests received from the laboratory were added to each patient s electronic documentation.

Questionnaires and observations. In order to collect the research material, the following were used:

- Analysis of test results. Results of measurements of blood pressure, body weight, height. Laboratory results: glycated haemoglobin, lipid concentration (triglycerides, total cholesterol, LDL, HDL).

- Standardized Social Support Scale (S4-MAD). The scale consists of 30 questions, with answers on a 5-point frequency scale: 1 - never, 2 - rarely, 3 - sometimes, 4 - often, 5 - always. The scale includes five subscales: nutrition (10 questions), physical activity (5 questions), feet care (6 questions), nicotinism (3 questions) and glycaemic control (9 questions). Maximum in each of the subscales the patient may obtain - 100 points. The higher the value of the points obtained, the higher the social support received by the patient. To calculate the results, the following instruction was used:

1. Score all items from 1-5. These are row scores for each item.

2. To calculate the row score for each subscale, add item raw scores and then divide it by number of items in that subscale.

3. To transfer row scores to a score ranging from $0-100$, use the following formula to calculate the final score: the subscale score $=[($ subscale row score -1$) / 4] \times 100$. 
The original scale has good internal consistency, Cronbach`s alpha coefficient equal to 0.94 [12]. For the Polish version of the scale, this alpha coefficient $=0.93$.

Statistical analysis. In order to verify the hypotheses, non-parametric analysis of the differences assessment was used: Mann Whitney (for 2 trials) and Kruskal Wallis (for more than 2 trials). Spearman rho correlation was used for quantitative and ordering variables. Statistical analysis was performed using the SPSS programme; relationships were significant from a statistical point of view when $\mathrm{p}<0.05$.

\section{RESULTS}

The clinical characteristics of 79 patients with diabetes included an average duration of 10 years $(\mathrm{SD}=8.7)$ of the disease. 47 patients were treated with hypoglycaemic tablets, 22 patients were treated with insulin as well as tablets, and 10 patients were treated with insulin only. According to the BMI index, 47 patients were obese and 29 were overweight. The value of systolic pressure in 28 people was $>140 \mathrm{mmHg}$, and high diastolic blood pressure occurred in 19 people. The value of glycosylated haemoglobin in a half of the patients (41 subjects) was above $7 \%$, in 38 subjects $\leq 7 \%$. Above normal LDL values $(>100 \mathrm{mg} /$ dl) were present in 26 people, HDL $(<40 \mathrm{mg} / \mathrm{dl}$ for women and $<50 \mathrm{mg} / \mathrm{dl}$ for men) - 33 people, triglycerides (>150mg/dl) - 36 people, 20 people total cholesterol $(>175 \mathrm{mg} / \mathrm{dl})$.

Patients with diabetes received the most support in terms of nutrition $(\mathrm{M}=46.9)$ and glycaemic self-control $(\mathrm{M}=39.9)$. They received the least support in the field of foot care $(\mathrm{M}=25.3)$ and smoking $(\mathrm{M}=27.4)$ (Tab. 1$)$.

Table 1. Social support in individual subscales $(n=79)$ - descriptive statistics

\begin{tabular}{lccccc}
\hline Sub-scales & M & Med. & SD & Min. & Max. \\
\hline Nutrition & 46.9 & 44.0 & 24.2 & 6.0 & 97.0 \\
\hline Physical activity & 34.3 & 35.0 & 22.0 & 0.0 & 85.0 \\
\hline Self-monitoring of blood glucose & 39.9 & 32.0 & 23.8 & 0.0 & 93.0 \\
\hline Foot care & 25.3 & 17.0 & 22.8 & 0.0 & 96.0 \\
\hline Smoking $(\mathrm{n}=53)$ & 27.4 & 25.0 & 21.7 & 0.0 & 83.0 \\
\hline
\end{tabular}

- 26 patient did not smoke

$+p<0.05$

* low correlation

** moderate correlation

With higher support in the area of cigarette smoking, patients' values of systolic $(\mathrm{p}=0.022)$ and diastolic pressure $(\mathrm{p}=0.000)$ were lower. It has been shown that respondents receiving greater social support in each support category are more likely to have normal diastolic blood pressure values $(\mathrm{p}=0.06)$ (Tab. 2).

Poor, statistically significant correlations indicate that diastolic RR decreases in the case of an increase in the value of physical activity support $(\mathrm{p}=0.016)$, glycaemic self-control $(\mathrm{p}=0.017)$ and foot care $(\mathrm{p}=0.010)$. The total cholesterol value decreases with more support in the area of glycaemic self-control $(\mathrm{p}=0.024)$ (Tab. 3).

Analysis showed two statistically significant differences that indicate that patients with normal $\mathrm{HbAlc}$ values receive greater support in the sphere of nutrition $(\mathrm{p}=0.028)$ and physical activity $(\mathrm{p}=0.017)(\mathrm{Tab} .4)$.
Table 2. Diastolic blood pressure and social support in various subscales

\begin{tabular}{|c|c|c|c|c|c|c|c|}
\hline \multicolumn{2}{|c|}{ Diastolic blood pressure } & 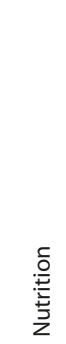 & 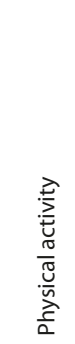 & 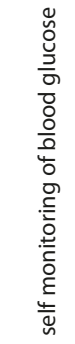 & 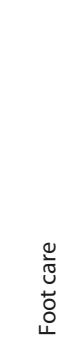 & $\begin{array}{l}\text { O } \\
\stackrel{\complement}{\frac{y}{0}} \\
\stackrel{\text { है }}{n}\end{array}$ & 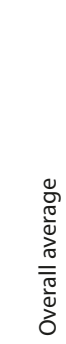 \\
\hline \multirow{3}{*}{$\begin{array}{l}<80-84 \mathrm{~mm} \mathrm{Hg} \\
\text { normal }\end{array}$} & M & 49.6 & 39.7 & 45 & 30.7 & 33.8 & 39.8 \\
\hline & Med. & 51 & 35 & 43 & 27 & 33 & 37,1 \\
\hline & SD & 26.9 & 19.1 & 25 & 23.7 & 21.9 & 18.3 \\
\hline \multirow{3}{*}{$\begin{array}{l}85-89 \mathrm{mmHg} \\
\text { elevated }\end{array}$} & M & 37.4 & 25 & 22.6 & 6.4 & 6.3 & 22.1 \\
\hline & Med. & 40.5 & 22.5 & 23 & 2 & 4 & 20.5 \\
\hline & SD & 20.6 & 24.5 & 5.3 & 7.9 & 8.1 & 12.1 \\
\hline \multirow{3}{*}{$\begin{array}{l}>90 \mathrm{~mm} \mathrm{Hg} \\
\text { hypertansion }\end{array}$} & M & 43.5 & 23.4 & 33 & 18.5 & 16 & 27.5 \\
\hline & Med. & 44 & 10 & 29 & 8 & 17 & 27.6 \\
\hline & SD & 16 & 24 & 20.2 & 18.9 & 14.7 & 13.9 \\
\hline \multicolumn{2}{|c|}{ p Kruskal Wallis test } & 0,375 & 0.012 & 0.007 & 0.002 & 0.003 & 0.006 \\
\hline
\end{tabular}

Table 3. Metabolic equalization rates and social support in individual MAD-4 sub-scales

\begin{tabular}{|c|c|c|c|c|c|c|}
\hline & 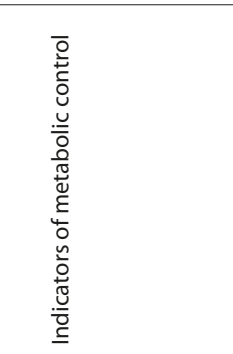 & 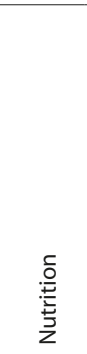 & 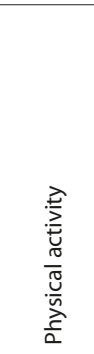 & 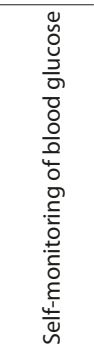 &  & 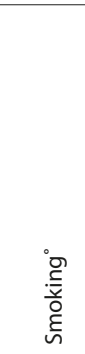 \\
\hline \multirow{2}{*}{$\begin{array}{l}\text { BMI } \\
\mathrm{kg} / \mathrm{m}^{2}\end{array}$} & Correlation factor & 0.023 & 0.045 & 0.109 & -0.013 & -0.067 \\
\hline & significance (duplex) & 0.841 & 0.696 & 0.338 & 0.907 & 0.633 \\
\hline \multirow{2}{*}{$\begin{array}{l}\mathrm{BP} \\
\text { systolic } \\
\mathrm{mmHg}\end{array}$} & Correlation factor & 0.063 & -0.175 & -0.219 & -0.121 & $-0.314^{* *}$ \\
\hline & significance (duplex) & 0.582 & 0.122 & 0.053 & 0.286 & $0.022 \dagger$ \\
\hline \multirow{2}{*}{$\begin{array}{l}\mathrm{BP} \\
\text { diastolic } \\
\mathrm{mmHg}\end{array}$} & Correlation factor & -0.068 & $-0.270^{*}$ & $-0.267^{*}$ & $-0.289^{*}$ & $-0.487^{* *}$ \\
\hline & significance (duplex) & 0.554 & $0.016 t$ & $0.017 \dagger$ & $0.010 t$ & $0.000 t$ \\
\hline \multirow{2}{*}{$\mathrm{HbA} 1 \mathrm{c} \%$} & Correlation factor & -0.162 & -0.186 & -0.070 & -0.090 & -0.041 \\
\hline & significance (duplex) & 0.153 & 0.100 & 0.542 & 0.430 & 0.769 \\
\hline \multirow{2}{*}{$\begin{array}{l}\mathrm{LDL} \\
\mathrm{mg} / \mathrm{dL}\end{array}$} & Correlation factor & -0.008 & -0.045 & -0.049 & -0.020 & -0.130 \\
\hline & significance (duplex) & 0.946 & 0.693 & 0.670 & 0.863 & 0.355 \\
\hline \multirow{2}{*}{$\begin{array}{l}\mathrm{HDL} \\
\mathrm{mg} / \mathrm{dL}\end{array}$} & Correlation factor & -0.071 & -0.029 & -0.049 & -0.009 & -0.162 \\
\hline & significance (duplex) & 0.533 & 0.798 & 0.665 & 0.940 & 0.247 \\
\hline \multirow{2}{*}{$\begin{array}{l}\text { Triglyceri- } \\
\text { des } \\
\mathrm{mg} / \mathrm{dL}\end{array}$} & Correlation factor & -0.031 & 0.073 & -0.021 & -0.005 & -0.082 \\
\hline & significance (duplex) & 0.787 & 0.523 & 0.853 & 0.966 & 0.560 \\
\hline \multirow{2}{*}{$\begin{array}{l}\text { Total cho- } \\
\text { lesterol } \\
\mathrm{mg} / \mathrm{dL}\end{array}$} & Correlation factor & -0.141 & -0.149 & $-0.254^{*}$ & -0.124 & -0.258 \\
\hline & significance (duplex) & 0.215 & 0.191 & $0.024 t$ & 0.275 & 0.062 \\
\hline
\end{tabular}


Table 4. HbA1c value and social support in each subscales

\begin{tabular}{|c|c|c|c|c|c|c|c|}
\hline $\mathrm{HbA1c}$ & & 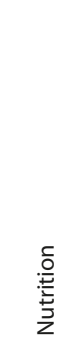 & 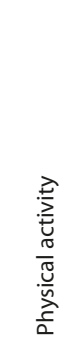 & 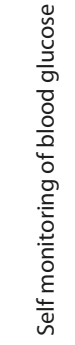 & 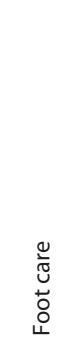 & 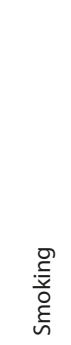 & 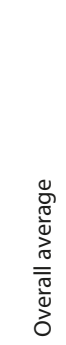 \\
\hline \multirow{3}{*}{$\begin{array}{l}\leq 7 \% \\
\text { normal }\end{array}$} & $M$ & 53.5 & 41.18 & 43.9 & 27.5 & 24.7 & 393 \\
\hline & Med. & 58.0 & 35.0 & 39.0 & 21.0 & 17.0 & 36.5 \\
\hline & SD & 25.4 & 21.6 & 25.8 & 24.8 & 20.9 & 19.8 \\
\hline \multirow{3}{*}{$\begin{array}{l}>7 \% \\
\text { too high }\end{array}$} & $M$ & 40.7 & 27.9 & 36.2 & 23.3 & 29.9 & 31.2 \\
\hline & Med. & 42.0 & 35.0 & 29.0 & 13.0 & 25.1 & 28.9 \\
\hline & SD & 21.6 & 20.61 & 21.4 & 20.9 & 22.7 & 15.4 \\
\hline \multicolumn{2}{|c|}{ p U Manna Whitneya } & 0.028 & 0.017 & 0.178 & 0.502 & 0,388 & 0,060 \\
\hline
\end{tabular}

\section{DISCUSSION}

In the treatment of type 2 diabetes, the aim is to maintain normal parameters of disease equalization [2]. Persistent or repeated states of hypo- and hyperglycaemia have their consequences in the form of chronic complications of diabetes. Daily management of diabetes is the basis for achieving optimal results [13]. This self-control, however, requires help from many sources of support, including relatives. Although it is still under discussion, a higher level of social support is often associated with better glycaemic control, increased knowledge about the disease, better treatment compliance and better quality of life [14]. Assessment of the patientss support and the use of non-pharmacological interventions seem to be necessary in the treatment of diabetes.

The aim of this study was to analyze the impact of social support on metabolic values equalization of diabetes. The first of the analyzed aspects was to determine the values of metabolic equalization indicators in the examined group. Analysis of the literature on the fulfillment of individual criteria for diabetes equalization shows that the most frequently met criterion is the value of diastolic blood pressure (66.9\%), and the least frequently the value of HDL [15]. Comparable values of diastolic pressure reached 66\% (52) of patients in own study. Normal values of HDL, ADL and triglycerides were demonstrated in about $60 \%$ of subjects, the percentage of patients with normal results compared to those of other authors is about $25-30 \%$ higher [16]. In the current study, the lowest percentage of normal results was recorded in the value of glycated haemoglobin $48 \%$ (32); however, this is comparable to the results obtained by Kudaj et al. - 50\% of patients [16]. In terms of lipid profile, LDL and HDL, the results of various authors seem to be consistent [17]. Only three of 79 patients had normal body mass. The problem of overweight and obesity in people with diabetes is highlighted by Field et al. [18].

Another aspect analyzed was the areas in which patients with diabetes receive support from close relatives. Own research shows that the social support received by patients is low, despite the fact that the analysis of diabetic patients' demand for support by Hawryluk et al. indicates that nearly $80 \%$ of diabetic patients expect family support [19]. In no category of social support analyzed in this study, did the patients receive more than $50 \%$ of the points possible to obtain.

The research carried out by Matej-Butrym et al. shows that about one-third of the respondents received a high level of support in the field of nutrition. Support received by one-third of respondents concerns regular meals, avoiding the consumption of simple carbohydrates, controlling the number of meals consumed, and preparing and eating meals together [11]. In the same study, high nutrition support included a slightly higher percentage of respondents and concerned warning against the intake of inappropriate meals, meal preparation and shared meals. In the Matej-Butry et al. study, support for the participation of a loved one in the purchase of dietetic food was at a low level, which is also reflected in own research. The results of studies by other authors confirm that a higher level of family support in nutritional therapy is associated with better lipid profile results [20], and lower values of glycosylated haemoglobin [21], which was confirmed by own analysis, accepting a HbAlc value of $7 \%$ as the target value in the treatment of diabetes.

In the area of physical activity, only one-third of the patients had a person who encouraged them to take regular physical activity, and even less a person who wanted to exercise with the patient. A low proportion of close relatives (44.6\%) in exerting pressure on regular physical activity of a diabetic patient was also demonstrated in the Matej-Butrym study [11]. However, looking at Polish society as a whole, only $21.8 \%$ meet the norms concerning the level of physical activity in free time recommended by the World Health Organization (WHO) [22]. People with diabetes receive little support in physical activity because family members or friends are also rarely active.

Researches shows that the risk of diabetes related complications can be reduced when patients maintain or control blood glucose at an optimal level. Independent management of diabetes is necessary to achieve this control [23] The lack of family participation in the self-monitoring of glycaemia in diabetic patients (75.2\%) is indicated by Matej et al. [11]. In own study, less than half of the patients had people who encouraged them to take measurements, and only 12 patients were reminded about the measurement. Among the respondents, the vast majority did not have anyone who would be interested in the results of glycaemic measurements. This is probably due to ignorance and still poor quality of education of the patient's family [24].

A study to analyze the relationship between social support, compliance with non-pharmacological recommendations and pharmacological recommendations, as well as clinical and metabolic control, was carried out by Gomes-Villas Boas et al. in a group of 162 patients with type 2 diabetes. The results did not confirm a relationship between social support and clinical and metabolic control variables, but demonstrated correlation with adherence to therapeutic recommendations [25]. In own study, even such the small level of support that patients received translated into the values of some clinical indicators of metabolic control. With increased support in the smoking subscale, patients achieved lower values of both systolic and diastolic blood pressure. In the studied group, more than half of the patients smoked, and support in this area was low. A significantly lower percentage of smokers (15\%) was demonstrated in the Kary et al. study [26]. Little access to anti-smoking clinics can make it difficult for patients to reduce smoking; for example, there are only 
19 institutions in the entire Mazowieckie Province that run a preventive programme of tobacco-related diseases [27]. Lack of support may also result from the fact that according to statistics, $29 \%$ of men and $17 \%$ of women smoke cigarettes daily. In the $50-59$ age group, up to $36 \%$ of men and $27 \%$ of women smoke [28]. In families in which tobacco is smoked, one can not expect high support in quitting smoking by a person suffering from diabetes. Smoking makes treatment of diabetes more difficult and alleviates glucose levels, contributes to higher glycated haemoglobin values and poorer metabolic control, compared to non-smokers. Cigarette smoking reduces the subcutaneous effect of insulin, which makes it necessary to increase its doses [29].

In the current study, as in that by Matej-Butrym et al., there was no correlation between glycated haemoglobin concentration and the level of support [11]. However, in the study by Thojam et al., actions in the area of diabetes self-control were more strongly associated with $\mathrm{HbA}_{1 \mathrm{c}}$ values in conditions of high social support [30]. Also, the results obtained by Gomes et al. showed that in the group of patients where a family member participated in education and was the source of support for the patient, the clinical influence of support was higher - there was a greater reduction in blood pressure and glycated haemoglobin in the intervention group than in the control group [31].

The results of 14 studies conducted by Stroma et al. showed a correlation between social support and improvement of clinical outcomes; a higher level of social support was also a positive factor in improving patient motivation in healthcare [8]. The study, which aimed to assess the impact of social support on behavior related to self-control, found that patients receiving higher social support, better monitor glucose $(69.4 \%)$, control diet (46.7\%), and are more physically active (31.2\%) [32]. The authors of the next study? confirmed that patients with diabetes receiving the strongest social support more often monitor glucose concentration, compared to other behaviors related to self-control of the disease [33]. As indicated in the literature, future initiatives in the field of self-monitoring programmes of type 2 diabetes should include mechanisms that allow measuring of social support.

\section{CONCLUSIONS}

The results of own research are important for the promotion of health and clinical practice. They suggest that healthcare professionals, whenever possible should include family members of people with diabetes for education and non-professional care in order to provide more support to the patients. The results of this study may indicate that healthcare workers should pay more attention to non-clinical factors when solving problems related to diabetes. They should also remember that interventions based on psychosocial approaches may not necessarily improve the metabolic control assessed by the values of clinical indicators, but they can affect the quality of life of patients.

Limitations. Two main limitations of this study have been identified. This study took place only in one diabetological clinic, thus limiting the generalization of these results to other centres. A small number of patients took part in the study which used convenience sampling, which means that only available patients were included in the study.
Acknowledgments. The authors would like to thank the head of the clinic, Piotr Raszczepkin, who agreed to the research and helped in collecting the data.

Funding. The study was performed without financial support.

Conflict of Interest. The authors declare no conflict of interest.

\section{REFERENCES}

1.International Diabetes Federation. IDF Diabetes Atlas, 8th edn. Brussels, Belgium: International Diabetes Federation, 2017. http://www. diabetesatlas.org Dostęp: 14.06.2019

2.2019 Guidelines on the management of diabetic patients. A position of Diabetes Poland. Clin Diabet 2019; 8, 1.

3. Trief $\mathrm{P}$, Ouimette $\mathrm{P}$, Wade $\mathrm{M}$, et al. Post-traumatic stress disorder and diabetes: Co-morbidity and outcomes in a male veterana sample. Journal of Behavioral Medicine 2006; 29(5): 411-418.

4. Cohen M, Kanter Y. Relation between sense of coherence and glycemic control in type 1 and type 2 diabetes. Behavioral Medicine 2006; 29(4): $175-183$.

5. Guevara C, Nicolalde M, Amoroso A, et al. Association between sense of coherence and metabolic control in people with diabetes mellitus type 2. European Scientific Journal 2018; 14(15): 1857-7881.

6. Rodin J, Salovey P. Psychologia zdrowia. In: Heszer-Niejodek I, Sęk H. Psychologia zdrowia. PWN-Warszawa 2007;25.

7. Łosiak W. Psychologia stresu. Wydawnictwo Akademickie i Profesjonalne-Warszawa 2008.

8. Strom J, Egede L. The impact of social support on outcomes in adult patients with type 2 diabetes: A systematic review. Current Diabetes Reports 2012; 12(6): 769-781.

9. Mayberry L, Osborn C. Family support medication adherence, and glycemic control among adults with type 2 diabetes. Diabetes Care 2012; 35: 1239-1245.

10. Kang C, Chang S, Chen P. Comparison of family partnership intervention care vs. conventional care in adult patients with poorly controlled type 2 diabetes in a community hospital: a randomized controlled trial. International Journal of Nurse Studies 2010; 47: 1363-1373.

11. Matej-Burym A, Burym M, Jaroszyński A. Impact of family help provided to the metabolic control of type 2 diabetes. Public Heath 2017; 122(3): 265-268

12. Naderimagham S, Niknami S, Abolhassani F, et al. Development and psychometric properties of a new social support scale for self-care in middle-aged patients with type II diabetes (S4-MAD). BMC Public Health 2012; 28(12): 1035.

13. McEwen M, Pasvogel A, Gallegos G, Barrera L. Type 2 diabetes self-management social support intervention at the U.S.- Mexico border. Public Health Nursing. 2010; 27(4): 310-319.

14. Ciechanowski P, Russo J, Katon W, et al. Relationship styles and mortality in patients with diabetes. Diabetes Care 2010; 33: 539-544.

15. Łagowska-Batyra A, Rudzki G, Matyjaszek-Matuszek B. Analiza spełnienia kryteriów wyrównania metabolicznego cukrzycy typu 2 w populacji pacjentów hospitalizowanych w Klinice Endokrynologii w latach 2006-2011. Diabetologia Kliniczna 2014; 3(6): 246-255.

16. Kudaj-Kurowska A, Turek I, Józefowska M. Wyrównanie cukrzycy u chorych na cukrzycę typu 2 w świetle wytycznych Polskiego Towarzystwa Diabetologicznego. Diabetologia Kliniczna 2014; 3(3): 92-99.

17. Fabian W, Majkowska L, Molęda P, et al. Wyrównanie cukrzycy typu 2 u chorych leczonych przez lekarzy podstawowej opieki zdrowotnej. Polskie Archiwum Medycyny Wewnętrznej 2006; 116: 760-765.

18. Field A, Coakley E, Must A. Impact of overweight on the risk of developing common chronic diseases during a 10-year period. Archives of Internal Medicine 2001; 161: 1581-1586.

19. Hawryluk J, Kostrzewa-Zabłocka E. Zespół wypalenia osobowości w cukrzycy typu 2. Zdrowie i Dobrostan 2015; 2: 207-221.

20. Chyun D, Lacey K, Katten D, et al. Glucose and cardiac risk factor control in individuals with type 2 diabetes: implications for patients and providers. Diabetes Education 2006; 32(6): 925-39.

21. Choi SE. Diet-specific family support and glucose control among Korean immigrants with type 2 diabetes. Diabetes Education 2009; 35(6): 978-85. 
22. Ministerstwo Sportu i Rekreacji. Poziom aktywności fizycznej Polaków 2018. Kantar Public 2018.

23. Huang IC, Wang PW, Liu RT, Tung SC, Chen JF, Kuo MC, Hsieh CJ., The influence of self-monitoring blood glucose frequency on the oscillation of hemoglobin Alc and chronic complications. Chang Gung Med J. 2012; 35(1): 46-53.

24. Otto-Buczkowska E, Marciniak-Brzezińska M. Specyficzne problemy edukacji diabetologicznej. Forum Medycyny Rodzinnej 2016; 10(4): 212-218.

25. Gomes-Villas Boas LC, Foss MC, Foss de Freitas MC, Pace AE. Relationship among social support, treatment adherence and metabolic control of diabetes mellitus patients. Rev Latino-Am Enfermagem 2012: 20(1): 52-58.

26. Kara I, Zysnarska M, Adamek R. Palenie tytoniu, alkohol i aktywność fizyczna wśród pacjentów z cukrzycą typu 2. Przegląd Lekarski 2012; 69(10): 944-946.

27.NFZ Mazowiecki Oddział Wojewódzki w Warszawie. Zdrowotne Programy Profilaktyczne. http://www.nfz-warszawa.pl/dla-pacjenta/ co-kazdy-pacjent-wiedziec-powinien/profilaktyczne-programy-zdrowotne/ Dostęp: 14.06.2019.
28. Główny Urząd Statystyczny. Notatka informacyjna. Zdrowie i zachowanie zdrowotne mieszkańców Polski w świetle Europejskiego Ankietowego Badania Zdrowia (EHIS) 2014 r., Warszawa 2015.

29. Śliwińska-Mossoń M, Milnerowicz H. Palenie tytoniu a rozwój, progresja i leczenie cukrzycy. Przegląd Lekarski 2011; 68(10): 1005-1009.

30. Thojampa S, Mawn B. The moderating effect of social cognitive factors on self-management activities and HbAlc in Thai adults with type-2 diabetes. International Journal Nurses of Science 2017; 1(4): 34-37.

31. Gomes LC, Coelhoa ACM, Gomides DS, et al. Contribution of family social support to the metabolic control of people with diabetes mellitus: A randomized controlled clinical trial. Applied Nursing Research 2015; 36: 68-76.

32. Khymdeit E, Rao A, Narayanan P, et al. Social support influencing diabetes self-management behaviors: A cross-sectional study in Udupi Taluk. Indian Journal of Health Sciences 2016; 19(2): 154-146.

33. Rosland A, Kieffer E, Israel B, et al. When is social support important? The association of family support and professional support with specific diabetes self menagement behaviors. Journal of General Internal Medicine 2008; 23: 1992-9. 